\title{
Owner-CEO Collaboration Case
}

\author{
by Elena Szederjei \\ (Switzerland)
}

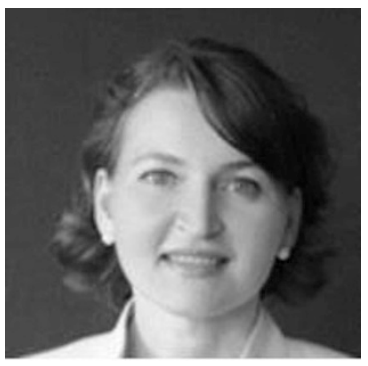

CND, The Swiss Data Center

International Center for Corporate Governance

\section{The Pros and Cons of an Owner-CEO Combination}

The entrepreneur Alexander Manberg founded and successfully developed an IT company over 30 years ago. He managed to do this from scratch using no external financing whatsoever. At the time he decided to plan for the company's succession, the company employed 40 persons and had an annual turnover of six million Swiss francs.

Once aware of the importance of planning for a succession, Alexander Manberg approached this task with considerable thoroughness. He not only wanted to be rewarded for his past efforts but wanted to ensure the long-term existence of the particular brand he had created. For the latter reason, he blocked all proposals for selling the company to any competitors and instead looked for an independent successor that had similar competencies to his own, viz. strong technical skills, a capacity to bear the many difficulties that are bound to arise when managing a company, and an awareness of quality that is typical of operations in Switzerland.

In the end, he was able to persuade a senior engineer within his company (albeit very talented and technically skilled) to become his successor and to take over the company. The deal involved external financing and this new owner was also appointed as the CEO.

Several months after his appointment, the new CEO recognised the need to adjust the company's strategy to the rapidly changing market conditions in the IT branch.

However, having little managerial experience and overestimating his responsibility, the new CEO blocked himself by fears of making unsound decisions. Finally, he was not able to believe in his own success and in the success of the business itself. This resulted in a negative impact on the company's overall performance. 


\section{Questions}

- What was the reason at the Board level for the company's negative development?

- Was the decision to look for a successor with the same personal profile a good one?

- How could the situation be improved?

\section{$3 \quad$ What Happened in Reality?}

The Board recognised that the new CEO was considerably deficient in financial skills. It had also recognised that an increased number of employees required professional guidance and control and this could not be executed by a person with strong technical skills alongside to his client servicing and strategic direction activities.

The Board decided to appoint an independent CEO. This decision released the tension of fears and restored a positive trend in company's development.

\section{$4 \quad$ What Can We Learn from This Case?}

1. Planning for a succession in a company is as a chance to strengthen that company by broadening its corporate knowledge and professional network. Market conditions are considerably different from what they were 30 years ago. Try to consider candidates with different skills! When the new successor has very similar skills to his predecessor, it could well be a good idea to support that person by employing a new CEO.

2. When starting from the size of 30 people, an independent CEO is recommended to increase the efficiency of operations and to free the resources for other activities.

3. An independent CEO can also be the solution when a company or the company's owners are facing financial pressure. This is likely to keep any awareness of business risk at a sound level, thereby seeing that any new opportunities are taken advantage of. 
Open Access This chapter is licensed under the terms of the Creative Commons Attribution 4.0 International License (http://creativecommons.org/licenses/by/4.0/), which permits use, sharing, adaptation, distribution and reproduction in any medium or format, as long as you give appropriate credit to the original author(s) and the source, provide a link to the Creative Commons licence and indicate if changes were made.

The images or other third party material in this chapter are included in the chapter's Creative Commons licence, unless indicated otherwise in a credit line to the material. If material is not included in the chapter's Creative Commons licence and your intended use is not permitted by statutory regulation or exceeds the permitted use, you will need to obtain permission directly from the copyright holder.

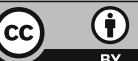

